Philosophy and Progress: Vols. LV-LVI, January-June, July-December, 2014 ISSN 1607-2278 (Print), DOI : http://dx.doi.org/10.3329/pp.v55i1-2.26391

\section{THE EARLY JAPANESE AND THEIR RELIGIO-CULTURAL LIFE: A HISTORICAL OVERVIEW}

\author{
Mohammad Jahangir Alam*
}

\begin{abstract}
Japanese Religion, in general, refers to the multiplicity of religions in Japan. Different religious traditions coexist in Japan for centuries after centuries without breaking interreligious harmony among them. The present work especially focuses the Traditional Japanese Religions as major elements of culture that are basically a mixture of folk religions, early Shinto, Confucianism, Daoism and Buddhism. Shinto has been the indigenous tradition for over two thousand years until it was synthesized with foreign elements. Buddhism, Taoism and Confucianism have profoundly influenced the spiritual and socio-political life of the Japanese since $6^{\text {th }}$ century AD. These religious traditions have long met, interacted and influenced each other and together formed the religious and cultural life of the
\end{abstract}

\footnotetext{
* Associate Professor, Department of World Religions and Culture,

University of Dhaka, E-mail : alam9363@gmail.com
}

Japanese people. Nonetheless, though the religious and intellectual life of the court was dominated by Buddhist and Confucian thought during the seventh and eighth centuries, Shinto remained the religion of the people and also became almost a part of the political machinery.

\section{Introduction}

Historically speaking, Japan is a comparative latecomer in the development of civilization, since cultural movements from Central Asia and China reached her late. Japanese written history prior to Christian era is based on racial characteristics, legends and little archeological discoveries. Therefore, not much is known about the early life, culture and religion of the Japanese. Before the introduction of Buddhism and Confucianism, the religion of the Japanese was an unorganized, undifferentiated, and unnamed complex of agricultural cult, nature worship, ancestor worship and shamanism ( Ichiro:ND:13). Indeed, the religion of those early Japanese was polytheistic nature worship. They believed that all natural phenomena were of animistic character and that each person or thing was in itself a manifestation of the divine entity. This belief system, as a part of the folk religions (syncretistic religious beliefs and practices) has long been the heritage of the common people (William, 1948:1). However, the main elements of Japanese higher culture are derived from China. For its superior culture, China has for long been the dominant power all over East Asia. As a result, Tibet, Mongolia, Korea, part of Southeast Asia and Japan always looked forward to China as a source of leadership and inspiration, a cultural stimulus, and a cultural storehouse. Even so, Japanese culture always remains distinctive. One of the most fascinating features of the Japanese is their capacity to borrow and adapt 
and still remains their own individuality and their own style. Indeed, the process of assimilating the spirit of an alien culture is always difficult. But the Japanese always made great efforts and showed great power of converting borrowed materials to their special purposes. They conceived their purposes deep within their national consciousness. Therefore, they molded a culture in a way that no one could mark anything foreign but Japanese. They could successfully accomplish that process of assimilation by the end of $8^{\text {th }}$ century A.D.

\section{Method and Objectives}

There are different approaches to the study of religion and religious life of the Japanese. This paper attempts historical approach in order to clarify the involvement of religion in socio-cultural and political life of the nation in the different historic periods; to show how the universal phenomenon "religion" began itself; and analyze the religious development in the cultural history of Japan from its obscure beginning to the early $9^{\text {th }}$ century A.D. Indeed, this was Japanese formative period. Stated somewhat differently, how did foreign thoughts and culture withstand the challenges into they faced there in Japan and where feasible turn those challenges into opportunities for survival and growth? Thus, the present study focuses a time period of thousands of years to make a new finding about how the Japanese learned the crafts of reading and writing; and began to be self-conscious about themselves as a people and about their destiny in the universe, political, cultural and religious spheres. Therefore, before the main discussion, this paper calls for a historical analysis regarding the development of the early period of Japan.

\section{The Origin and the Early History of the Japanese}

The early roots of the Japanese are mixed and obscure. Archeological records make it certain that there were other non-Japanese races living on the islands of Japan before the arrival of the Japanese themselves. One of these races, the Ainu of Caucasian type, still survives to the present day. For centuries they dominated the northern part of the islands. They are now reduced to a small group living on Hokkido only. The Japanese, on the other hand, are of Mongolian race with faces on the whole flatter than the Caucasian type (Morton, 1970:5). It is argued by some that a reservoir of Mongolian people came to Japan from the Siberian North who would live there in prehistoric time. Historians agree, however, there was a Mongolian invasion of southern and central Japan via Korea. Two more exact areas are discovered for Mongolian people who mingled to form the Japanese race. The first is Central Asia. The physical type and the language they spoke provide evidence for this case. The second area of origin for one of the Japanese strains refers to South China region. This is proved by certain physical features which match the people of South China more closely than those of North. In addition, certain items of diet point to the same region. A third possible area also points to Southeast Asia and the pacific islands. This is controversial, though. The main argument for it is found in the form of architecture used in the old Japanese farmhouses and in the Shinto shrine buildings. The style and structure of the buildings correspond to those of Malaysian and Polynesian ones. In fact, this theory has been objected that the islanders could never have covered the distance from the South pacific islands to Japan in open boats and without navigational aids. But the present-day Polynesians are known to be able to sail immense distances with remarkable accuracy in outrigger canoes with similar navigational devices. Therefore, their 
present day expertise in navigation attests to their skillful Polynesian forefathers who might have sailed a long way up to Japan. Thus, the Polynesians' origin may also be considered as one of the Japanese strains. But whether people believe it or not, legends ensure that the people of Japan are the descendents of the Sun Goddess and thereby their land is characterized as divine. However, though the Japanese are from different areas they remain a distinctive group, conscious of their cultural heritage, having some ties with the mainland but living their separate life as an island people. There are three sources of information about ancient Japan, namely, Japanese archeological evidence, Chinese written records and mythology. In fact, the transition (from mythology to history) does not provide any historical evidence of the founding of the Japanese nation.

\section{i. Archeological Evidence}

To understand the prehistoric contribution to Japanese religion and culture, we have to synthesize the archeological evidence that precedes written records. If the very earliest archeological finds (possibly Paleolithic) are excluded, the bulk of this evidence falls into two prehistoric periods called the Jomon and the Yayoi, followed by a transitional period called Kofun, which shade into early history. There are a few evidences of Old Stone Age remain in Japan. The first major culture group dates back to Mesolithic or Middle Stone Age as its earlier stages that began as early as 6000 B.C. or as late as 3000 B.C. and continued until 250 B.C. (This culture is known as the Jomon-the "cord pattern.” The Jomon people would make hand thrown pottery; used stone weapons; and lived in sunken-pit dwelling. They did not practice agriculture but lived by gathering roots, nuts, and small games (animals hunted for food) from the forests and shellfish from the shore. Therefore, the main evidence for the culture of this period is usually considered Neolithic (Earhart, 1982:24). Like many Neolithic cultures, Jommon religion emphasized fertility. Female clay figures, perhaps goddesses or earth mothers, have been found at Jommon sites while male phallic representations found at household shrines. Other aspects of Jommon religion also suggests snake cult, clay masks etc. Serpents are also found to be associated with fertility while clay masks might have been used by shamans. Jomon culture also produced frequently decorate pottery and many remarkable clay figures known as dogu-unusual but finely crafted, half-animal, half-human figures with peculiar eyes of long narrow opening. All of those Jomon religio-cultural aspects exhibit a brilliant fusion of the religion and art. Broadly speaking, Jomon culture and religion were probably comparable to that of Polynesia and Melanesia at the time of initial European contact. The next culture group appears much later between 300 B.C. and 100 B.C. who are known as Yayoi. Although early discoveries of their presence were made from a site in Tokyo, in fact, this culture was strongest in west Japan. They are reported to have produced wheel-made pots and certainly practiced advanced type of agriculture similar to the Chinese pattern. As they apparently used both bronze and iron together, they cannot be said to have undergone a separate Bronze Age period. Being on the last stage of Asian civilized era, presumably Japan received bronze metal techniques slow and late. Among the Yayoi archeological remains are mirrors, bells, swords, and spears of bronze. In fact, ornamental bronze bells and ceremonial weapons, as distinctive features of Yayoi culture, show a remarkable affinity with religion, and of course, historical Japan. Yayoi religion was centered on agricultural rites and shamanism. The niiname, for example, the harvest festival became crucial to Shinto and the rites of the imperial house. Perhaps, this religious cult of Yayoi culture continued down 
through the centuries. Female shaman, especially, had important roles both among the common people and as oracles on matters of state (Ellwood: 20-21). Later, about the middle of the third century A.D., the Tomb (Kofun) culture replaced the Yayoi culture, though it did not altogether replace. The Tomb culture is differentiated by the building of stone burial chambers and huge earthen mounds, reaching 1500 feet in length and 120 feet in height (Morton:8). These greatest numbers of tombs are found in the Yamato area, and sophisticated ones belong to the early emperors of the historic imperial line. Within the tomb the body was surrounded by sacred mirrors, swords, and jewels, remarkable paintings and accoutrements (such as "soul boats"). They apparently designed the tomb so the spirit of deceased could ferry to the other world. It should also be noted that first three items are still the sacred regalia of the Japanese emperor. These tombs are similar to burial places in Korea and Northeast Asia that indicate further continental influence on Japanese culture in the earlier periods. Generally speaking, however, it is conjectured that during the Jomon period animistic beliefs prevailed, and that during the Yayoi period the practice of ancestor worship was established. The worship of kami (spirits of nature, clan deities, or gods), the practice of ritual purification, and the use of divination and oracles delivered by the shamanic mediums were all prominent features of early Shinto practices (Yusa, 2002:13).

Notable to mention that before Yamato Izumo had a higher culture. The importance of Yamato for a hundred skilled workers in clay are said to have been brought from Izumo by Nomi-no-Sukune. He was the reputed inventor of the haniwa (clay figures) used to take the place of human sacrifices previously buried alive in standing position at the funerals of the great. The whole process of recording and editing the legends indicates that (long before 712 A.D., the date of publication of the Kojiki-Records of Ancient Matters) the Yamato clan leaders had become the dominant figures in Japan. In addition, when the position of the imperial clan was stable enough, they (Yamato people) began to promulgate a version of the early legends which exalted the place of the Yamato ancestress-the Sun Goddess, over the Izumo ancestorthe Storm God. Their political center was firmly established by the third century A.D. or earlier in the fertile land of the Yamato region. The north of the main island was still in possession of the Ainu while the central and western portions of Japan were controlled by that amalgamation of peoples we know as the Japanese. Their society consisted of a number of semi-independent clans, or uji, under the general leadership of the Yamato clan. Each uji claimed descent from a common ancestor. They were united under a clan chief and worshiped the god of the clan (Ichiro: 13).

\section{ii. Chinese Written Records}

Only a few of the earliest written records concerning Japan are the Chinese documents such as, the Wei Chih- "History of the Kingdom of Wei" (220-266AD, present day Xuchang, Henan Province in Northern China) and the Wei zhi (Record of Wei) written in $3^{\text {rd }}$ century A.D. In fact, the third-century Chinese chronicles are responsible for Japan's most enduring ancient mystery. According to these chronicles, the Chinese of the Han Dynasty established a colony in Korea in 108 B.C. The Han Chinese, thus, became more closely aware of Japan, and the first visit of a Japanese envoy to the Han court is recorded in 57 A.D. This early history tells of a group of islands off the China coast that were dominated by a female shaman priest named Himiko or Pimiko for more than half a century as head of the largest chiefdom, traditionally known as Yamatai, until her death in 248. There were many principalities while 
Yamatai was chief among them. Generations of historians have debated "the Yamatai controversy" (Kitagawa : 5-6) and have hypothesized numerous localities. General consensus centers around two likely locations of Yamatai, either northern Kyushu or Yamato Province in the Kinki region of central Honshu. According to Chinese records, some principalities sent envoys to China in different times from 57A.D. to 266A.D. They are found to pay tribute to Chinese monarchs. In addition, by 367 AD, Japan appears to have acquired sufficient political and military power to invade Korea and established a colony called Mimana at the southern tip of the Korean peninsula. Japan continued to exchange envoys with Korea from 366 to 562 until it was destroyed by a rival principality called Silla. In case of China, however, the sending of Japanese envoys was terminated from 266 A.D. until further tribute was sent in 413, 421, 478 and 503 (Ibid: 5-7). According to the book, History of the Kingdom of Wei, the land of the Wa (the Japanese people) was located in the middle of the ocean. The Chinese chroniclers also describe the customs and manners of the Wa. For example, men tattooed their faces and decorated their bodies with designs; they fastened their clothing loosely around the body; and women wore dresses (short, more than single pieces of cloth) and hair in loops. People were familiar with agriculture and sericulture (raising silkworms in order to obtain raw silk). They produced fine linen and silk fabrics. They enjoyed liquor and believed in divination (prediction uttered under divine inspiration- divine judgment, divine guidance, divine will, divine worship etc). They created and observed strict social distinctions (Ibid: 5-7). The records of the first ten or more emperors of the founding of the Japanese nation in both Kojiki (Records of Ancient Matters) and Nihongi (Chronicles of Japan) are historically unreliable. But they are very valuable in religious terms. The Nihongi and the Kojiki, the official chronicles of the times, devoted much space to early mythology and the "age of the deities" (Bunce: 7). No doubt true that they have played a crucial role in Japanese history. It is difficult to determine how much of the Nihongi was based on actual native mythology and how much it was invented to glorify the imperial families, but it evidences foreign influence in parts and, as an official chronicle, contain many historical absurdities. It served its purpose, however, and became the Bible of Shinto. These accounts describe the earthly counterpart and extensions of the mythical events in heavenly domain. (Ibid: 7).

\section{iii. Japanese Mythology}

There are voluminous literatures on Japanese mythology which are mostly very difficult to interpret. The undoubted historical traces within it are hard to separate from the legendary materials. However, the Shinto legends, the third source of information about early Japan, represent a primal pair, Izanagi, the male god and Izanami, his consort who formed the sacred islands of Japan (earthly paradise) through a supernatural process. According to another version, the islands were emerged from the divine union in marriage of the god and goddess. In any event they descended to live on the islands, and had children who were the gods and goddesses of the land. Perhaps the Japanese concept of Izanagi and Izanami may have been adopted from the Chinese supposition of Yin and Yang, the principal causes of creation.

Nonetheless, myths are not always meaningless. Sometimes they provide history with valuable clues. Shinto legends, for example, refer to some specific geographical locations such as Izumo and Kyushu that contain references to actual political and military events. Archeological research, in fact, points to Kyushu as an early site of Japanese civilization. Indeed, this is 
confirmed in the legend which relates that the divine grandson of Amaterasu, Ninigi-no-mikoto, came down from Heaven onto a mountaintop in Kyushu. According to the Kojiki and Nihongi, it was Ninigi's great-grand son who became first legendary emperor named Jimmu-tenno. The ancient records call Jimmu-tenno (Divine-Warrior Emperor) the first human emperor of Japan. The traditional date in the Kojiki reports Jimmu to have established his throne in Yamato in 660 B.C. and thereby their land is characterized as divine. The tradition and story, however, go further: The islands were a creation of the heavenly kami as well as a mirror image of the heavenly abode and thus, in effect, an earthly paradise. Moreover, the paradise was not only peopled by humans but also from a very early time peopled by both earthly kami and heavenly kami for the benefit of the land and its population (Ellwood, 1985:8384). Following Jimmu, the legendary genealogy informs about a series of emperors with unusually long terms of one hundred years or more. Curiously, the Nihonshoki describes the long and eventful career of the tenth emperor Sujin in the same way it does that of the first emperor Jimmu. And both Jimmu and Sujin are called the "Hatsukunishirasu-sumera-mikoto" (The Emperor, the August Founder of the Nation (Kitagawa: 8). The similarity of their careers as unifiers of the nation has caused many scholars to speculate that the accounts of the two emperors, Jimmu and Sujin, in the Nihonshoki actually refers to the same person. However, dating in the whole early period is highly conjectural and not become even moderately reliable until 400 A.D. And the imperial clans may have been established as rulers by the third century or possibly the fourth.

However, there are indications all in three sources (archeology, Chinese records and legend) of the existence of close ties and a significant two-way traffic between Korea and early Japan. Workers in certain specialized crafts could be obtained only from China and Korea. Such skilled men along with their leaders were readily welcomed in Japan while the leaders seem to have been accepted without question into the ranks of the Japanese nobility. As a book of genealogies of 815, for example, shows that over 33 percent of 1182 families of the Yamato nobility were of foreign, that is mainly of Korean origin (O. Reischauer, 1958:471). More specially, the Japanese established a bridgehead on the south tip of the Korean peninsula in 369 and maintained their occupation until 562 A.D. From this base the Japanese force moved against the king of Koguryo who was the enemy of the king of Paikche. Consequently, being grateful for the help of the Japanese he dispatched some scholars trained in the Chinese Classics to the Japanese court who brought with them a copy of the Thousand Character Classic and possibly also a copy of the Analects of Confucius. Thus, the Yamato kingdom by the fifth century or earlier was sufficiently centralized to exercise some control in Japan. The next stage of Japanese history saw an extension of the Chinese influence to Japan in such a degree that all subsequent Japanese civilization would be affected by it.

\section{The Introduction of Chinese Thought and Culture-Asuka Period (552-710)}

In Japan, Certainly Han Chinese Confucianism with its classical texts and Korean scribes had been introduced from Korea about 400 A.D. Indeed, the first example of Confucian ethical and political principles are understood and utilized after two hundred years through Prince Shotoku Taishi's (572-621) promulgation of the famous "Seventeen Article Constitution" (Smith, 1937:5-7) in 604. On the other hand, the official date for the introduction of Buddhism to Japan is 552, when the image and cult objects were sent by the king of Paikche of Korea in a view of receiving in return military aid against his 
enemy. In fact, images, sutras, and priests arrived in Japan via Korea before this date. During the Asuka period (552-628) the heads of many great families adopted Buddhism and vied with each other in building magnificent Buddhist temples. A great number of Japanese scholars and religious leaders were sent to China for study and training. With the introduction of Chinese civilization on a large scale, Japan emerged from the primitive stage of her existence. Confucian ethics and the practical politics embodied in its teachings revolutionized the Japanese concept of the state. As communication with the mainland improved, the Japanese were deeply impressed by the might and magnificence of the Chinese government. And they earnestly set about to develop a similar system (Bunce: 5). The effort culminated in the great Taika Reform of 646 which gave Japan a government modeled on that of the Confucian based government of China. Government support of the new religion was far-reaching that, in 655, an official decree was issued ordering the construction of Butsudan, small Buddhist altars, in all households of the nation. It must not be supposed, however, that the native religion died out. Moreover, despite the great favor shown to Buddhism by the court, there was a significant revival of the native religion towards the end of the seventh century. It was now given the name Shinto (way of gods) to distinguish it from Buppo (the way of the Buddha). Shinto had by this time developed a dual nature: it retained the simple, animistic ritualism of the traditional nature worship, and it produced an elaborate cult deliberately fostered by the Yamato clan as a political expedient. The Sun Goddess is the central figure of this cult (Ibid: 6). By the sixth century, the Sun Goddess cult had been accepted by the whole nation. Therefore, the Sun Goddess shrine at Ise became a national sanctuary where ceremonies were conducted by virgin imperial princesses. For the Taika Reform, an independent Department of shrines (Jingikan) was established under the administration of an imperial prince. This department was in charge of all rites and festivals that were guaranteed by the national laws. And Shinto began to be assumed the aspects of an official cult. As a system of thought, and a bearer of artistic ritual, Buddhism impressed the Japanese with its own sophisticated tradition of iconography (sculptures and paintings of various figures in the Buddhist pantheon), symbolic architecture (for example, the pagoda), literature in the form of scripture, and ritual performing arts (music, chant, dance, dramas, etc. (Ellwood: 86). The spirit of many Japanese responded to the beauty and solemnity of its worship. Prince Shotoku is notable above all for his policy of leading Japan to adopt Chinese models in the spheres of politics, religion and art. He accomplished it in three ways: the promulgation of a constitution of seventeen articles, the adoption of "cap rank" at the Japanese court, and the sending of the first official embassy to China in the name of the ruler of a united Japan in 607 (Bunce: 20). He led the movement for the conscious introduction of new forms of religion, philosophy, art, and political organization into Japan. In order to propagate the universal religion he took several steps: 1. Like other Asian rulers, Shotuko also built many temples and monasteries, 2. Allowed applicants to take orders and gave political and economic protection to monks and nuns, 3. Donated lands to temples and monasteries, and 4. Procured scriptures and statues from other lands. Besides establishing numerous monasteries, he founded Horyu-ji Temple in 607 (Hajime, 1967:14). This temple is considered the oldest wooden architecture in use in the world. Surprisingly, this custom of cultural and technological borrowing is recognized as a Japanese trait. Indeed, this is the distinctive manner of the 
Japanese in which they have always been able to assimilate borrowed material and make something of their very own out of it. They frequently succeeded in improving upon the original. The leadership in speculative thought and the creative influence of the religion upon arts gradually passed from China to Japan. Buddhism itself provides a major example. The whole process took centuries because Buddhism was not easily grasped. Even in modern technology, Japanese mastery and advance has been much more rapid, but the principle of thorough assimilation and intelligent application is the same. In A.D. 618 China became the largest, well organized, and culturally most advanced nation in the world. Therefore, the Japanese who visited China in search of new religion and new arts were tremendously impressed with the magnificence of T'ang Dynasty in that particular period. The Japanese were fortunate to be visiting China just before and during the T'ang Dynasty. They took home with them two basic systems of thought namely, Confucianism and Buddhism. The influence of Confucianism had a marked and lasting effect upon Japanese political thought and institutions. These systems of thought not only brought with them new ways, new lifestyle, and a degree of sophistication but also a number of arts and crafts. Although Japan is indebted to China for the general shape of its political structure, there were some very significant differences between the systems of the two countries. The following examples will give idea of the nature of differences. First, the primacy of the Department of Worship was a distinctly Japanese innovation. The second, difference lies in the methods of recruitment and appointment of officials. Third, the matter of exemption from the taxes set up in the Taika reform (Taika Reform of 645 meaning "great change” or "great reform”).

\section{The Stimulating Effect of Chinese Culture (Nara Period: 710-794)}

The influence of Buddhism on the spiritual and cultural life of the court during the Nara period was tremendous. It is noteworthy that about this time (Nara Period) the Japanese began to conceive of their nation as an empire and first to speak of their ruler as an emperor. Under the patronage of the imperial court, Buddhism prospered. After a period of 70 years, sectarian differences appeared in Japan, and eventually six sects were introduced from China. These were the Sanron (625), Jojitsu (625), Hosso (654), Kusha (658), Kegon (736), and Ritsu (754) sects (Bunce: 7). In 710 A.D. the engrafted shoots of Chinese culture and especially of Buddhism began to flower and soon bring forth fruit which was truly indigenous and Japanese in nature. Buddhism continued to grow and proselyte an increasing number of devotees, mainly from the upper ranks of society. A noteworthy fact is that Buddhism adopted the same strategy in case of China and Korea and had a remarkable achievement. In case of Japan, however, genuine religious motives were mixed with political ambitions. But soon after a thorough establishment of the new religion it was no longer dependent on the favor of clans. In addition, it got support from the court and the Taika reformers, following Prince Shotoku, took the same line. In the long run Buddhism exercised a refining and civilizing effect upon the rude warriors of early Japan. It revealed to them the power of gentleness and opened up perspectives on the problems of life, death, and suffering.

The sense of exclusiveness and necessity of deliberate choice that cause Westerners to adhere to one religion only are notably absent in East Asia. Neither the Chinese nor the Japanese people have difficulty in regulating their lives by the ideas of 
more than one faith at the same time. An official might, for example, attend a national festival such as the New Year ceremonies, conducted according to Shinto rites, but have a Buddhist service celebrated for the repose of his mother's soul, and apply Confucian canon to his government administration, without the least sense of inner contradiction. As a religion, Buddhism is the dominant factor in the history of the whole Nara period, not only in the realms of religion and culture but also in economics and politics. The reign of the Emperor Shomu (729-748), a sole supporter of Buddhism, was famous in art history. By the time of his reign, Buddhism was sufficiently established and Shinto divinities were believed to be the manifestations of Buddha. Following this theory Amaterasu, the Sun goddess, was worshiped as Vairocana, the great Buddhist deity who ruled over a world of light (Ibid: 31).

Though the Asuka and the Nara periods witnessed frequent succession, they also saw quarrels, abdications, assassinations, and struggles within the major families of the ruling clans. In the confusion of the times, Buddhist monks grew increasingly powerful in the capital at Nara. Buddhism became an increasingly aristocratic religion and corrupt hierarchy emerged within the monasteries. Under such circumstances, monasteries grew enormously wealthy and acquired vast, tax-free estates. Ambitious priests became involved in political intrigues. The ideological conflict with Shinto and the meddling of Buddhist priests in politics became distasteful to certain powerful factions at court. Here a clear paradox is marked between the dealings of the monks and the essence of Buddhist teachings. Finally, immediately after the full control of Fujiwara family over the government, the seat of government was shifted to a new capital in order to remove the priest-ridden political extravagances of Nara.

\section{Early Heian Period and Ryobu Shinto (794-810 A.D.)}

This section of the present work reflects the time span of Heian period up to the early $9^{\text {th }}$ century A.D. In 784 the imperial court left Nara and ten years later established a new capital, Heiankyo ("peaceful capital") in Kyoto in 794 A.D (Yusa: 13). The capital was inaugurated with political and religious reforms. Therefore, this period was called the golden age of classical Japanese culture and imperial court society. Historically speaking, the Nara was first affected by the powerful Fujiwara family. At the same time the Heian state was nominally ruled by the emperor, but real power was held by the Fujiwara family. The most powerful Fujiwara rulers became virtual dictators (Elwood: 31). As a result, the provincial rulers being impatient under the restriction of the central rulers became less pleased with Fujiwara domination. Such an unpleasant situation led the Heian state to be weakened and finally felled by complex struggles, on the one hand, between the Fujiwara and retired emperors, and on the other, between the capital and the restive warlords in the provinces. Psychologically speaking, in fact, it was the growing gulf between the court and the warrior class that precipitated the end of the Heian period. However, Heian religion appears in the literature and general culture more as bits and pieces, and as instruments of mood and feeling, than as systematic philosophy and practice. Institutionally, Heian religion was dominated by two great Buddhist denominations, Shingon and Tendai. Each was founded by a powerful charismatic leader named Saicho and Kukai. They appeared at the turn of the century (early ninth century) and brought about the transformation in Buddhism. Here, the rulers other's focus, the more practical one, considered the logistics of how religious reformation might be successfully established while adjusting to conditions in Japan during the early Heian period. 
Notably, Emperor Kammu (781-806) sent Saicho and Kukai to China to find and bring back a more spiritual form of Buddhism. It suggests that the court, like Asuka and Nara periods, kept patronizing Buddhism in a different way. However, on their return, Saicho founded the Tendai sect in 805 and kukai founded the Shingon sect in 809. Their teachings and the sects they established dominated the spiritual and cultural life of Japan for centuries. Their teachings include certain concepts that make salvation available to all. Nara Buddhism had been an exclusive and discriminating faith while this universality of salvation was an important factor in popularizing Buddhism (Ibid: 9). But one of the most important factors in the rapid spread of Buddhism among the lower classes was the merging of Shinto deities with those of the Buddhist pantheon. Though this attempt was first made in the Nara period, this effort fruited during the time of Saicho and Kukai. According to Saicho, Buddhist and Shinto deities were identical and succeeded in part in merging the two religions. On the other hand, Kukai propounded a new incarnation theory which stipulated that the central Buddha appears in different forms at various places in order to save mankind. In addition, he argued that the national deities of Shinto were incarnations of Buddha and Bodhisattvas. He further argued that as there was no distinction between the worship of Buddhist deities and those of Shinto, there were no basically conflicting elements in the two religions. Therefore, he identified Buddha with the Sun Goddess and lesser Buddhist deities with lesser Shinto deities. He termed this combination of the two religions as Rybu (dual aspect) Shinto.

Buddhism, however, dealt with the matter from a different angle. It declared that Shinto deities were derivative manifestations of the Buddhist deities which were regarded as original entities. As a result, Buddhist priests took charge of
Shinto sanctuaries while Shinto priests began to play only minor parts in the ceremonies. Indeed, the Buddhist influence became so strong that the form of Shinto rituals and celebrations, the decorative effects in the shrines, and even the images of native deities took on Buddhist flavor without question. However, the synthesis was never complete. There developed a division of duties: Shinto deities preside over the affairs of this world, while the life hereafter became the concern of Buddhism. Births, marriages, seasonal festivals, and victories in the battle were in the sphere of Shinto interest. Preaching doctrinal matters, ecclesiastical organization, and funerals were the responsibility of Buddhism. Ancestor worship, however, under strong Confucian influence had become a universal practice.

\section{Conclusion}

Though the origins of the Japanese people are mixed and obscure, one thing is certain that the Ainu of Caucasian type, the non-Japanese, held this land since Neolithic times (beginning about 10000B.C.). At the same time, other races of non-Japanese character lived on the islands before the arrival of the Japanese themselves. Their totem was the bear, and their way of life that of hunters and fishermen. Next culture groups such as The Jomon, and the Yayoi (advanced type races) appeared in Japan much later, between 6000B.C. and 100B.C. Archeological discoveries provide evidences for such groups. Therefore, a question arises: when did the Japanese come to Japan? In fact, there is no definite date of the advent of the Japanese to the islands. Presumably, the Japanese started to come to Japan about the early fourth century B.C. For, cultural progress between 300 and 100 B.C. in Japan refers to the Yayoi people to be one of the first groups of the Japanese who might have come to Japan earlier. In early historic times of the Christian era, Confucian, Taoist, and Buddhist elements moved 
into Japan seeking reconciliation with the native kami (Shinto pantheon). Japan has adopted various cultural and religious traditions and therewith enriched her spiritual life. Throughout this history, a Japanese religious synthesis made up of all these factors blended together. The nation's leadership and general public appreciated foreign traditions and very constructively coped with their original tradition that was integral to Japan. In this process the newly introduced traditions did not uproot the indigenous rather assimilated into a kind of homogeneous tradition which itself might be called "Japanese religion" (Ichiro: 12). From the seventh century on, Japan enjoyed peace and prosperity. During this period, the foreign culture imported was absorbed into a new and distinctive Japanese culture. The Nara and Heian periods, for example, produced great achievements in art, literature, architecture and clearly showed Japanese inventiveness. Finally, The Japanese applied their own creative genius to original Chinese patterns and no longer relied on China for inspiration.

\section{References}

Ichiro, Hori et al., Japanese Religion A Survey by the Agency for Cultural Affairs, $N D$.

K. Bunce, William, Religions in Japan, Tokyo, 1948.

Morton, W. Scott, Japan: Its History and Culture, McGraw-Hill Inc. New York, 1970.

Kitagawa, M. Joseph, Religion in Japanese History, Columbia University Press, New York, ND.

Ellwood, Robert, Japanese religion: A Cultural Perspective, Prentice-Hall Int., Inc, London, 1985.

O. Reischauer, Edwin, and K. Fairbank, John, East Asia, The Great Tradition, Boston: Houghton Mifflin, 1958.

Yusa, Michiko, Japanese Religions, London and New York, 2002.
Smith, W.Warren, Confucianism in Modern Japan, A Study of Conservatism in Japanese Intellectual History, Tokyo, 1937 ( the "Seventeen Article Constitution" was on the duties of people towards their sovereign and the need for harmony among inferiors and superiors).

Earhart, H. Byron, Japanese Religion: Unity in Diversity, Belmont, California, 1982.

Hajime, Nakamura, A History of the Development of Japanese Thought, Vol. 1, Tokyo, 1967. 